\title{
Nigeria and the Challenges of Internal Security in the 21st Century
}

\author{
Chris I. Nwagboso, Ph.D \\ Lecturer, Department of Public Administration, Faculty of Social Sciences \\ University of Calabar, Calabar, Nigeria
}

\begin{abstract}
This paper examines the various internal security challenges confronting Nigeria in the 21 st century. The paper adopts historical method and content analysis to investigate how the abysmal failure of the poorly formulated and ineffectively implemented National Security Policy has hitherto exacerbated internal security challenges in Nigeria. The paper further attempts a critical review of major internal security challenges hitherto confronting the country; such as the Niger Delta crises, kidnapping in the South-East geo-political zone, Jos crises, Boko Haram crises and crises by Fulani Herdsmen in the Northern part of Nigeria. The result of the analysis shows that these internal security challenges have not only been difficult to address by the National Security Policy, but have also impacted negatively on the country's desired socio-economic development in the 21st century. The paper, therefore, recommends among others, the need for a careful review of the Nigeria's National Security Policy that will not only be integrative/comprehensive in outlook, but will also take cognizance of some domestic factors that are currently responsible for internal security problems in the country; such as unemployment, inequality, poverty, fraudulent electoral process, corruption, skewed federalism, porous nature of the Nigeria's borders, sabotage among politicalelites, bad governance, religious intolerance, citizen-settler controversies, among others.
\end{abstract}

Keywords:Public Policy, Internal Security, Implementation, Economic Development.

\section{Introduction}

The Nigerian state has witnessed plethora of security challenges, especially since the enthronement of democracy in 1999. As a leading state in the African continent, available evidence shows that Nigeria has peculiar security challenges which some observers had expected the internal security policies (a component of the National Security Policy of Nigeria) to address. In Nigeria, ritual killings, cyber crimes, car theft, carjacking, advanced free fraud, drug trafficking, human trafficking, among others; have continued to pose serious challenges in Nigeria. As it was

the trend in some states in Africa like Ghana, Liberia, Sierra Lone, Gambia, etc. these security threats were witnessed along other non-violent threats such as HIVIAIDS, cholera, bird flu, Lassa fever, among others.

Beside these conventional threats, Nigeria is plague with violent security threats. However, such threats include the Niger Delta crises, Kidnapping, Boko Haram crises and frequent clashes between farmers and herdsmen in the Northern part of Nigeria. However, some of these threats have long historical antecedents, while others like the menace of Herdsmen are recent occurrence. In Nigeria for instance, armed robbery, arson, murder, rape, car theft, among others are not new. They are among the old internal security problems confronting the Nigerian state. Paradoxically, Nigeria in recent times witnessed new forms of security threats in her internal security management. Such threats were undoubtedly crimes perpetrated by Niger Delta Youths, Boko Haram sect, kidnapping by youthsfrom the South-East some other zones, terror-attacks by Islamic extremists in Jos, frequent attacks to farmers by Fulani Herdsmen and killing of Christians by extremists at southern part of Kaduna State; which is also located in Northern Nigeria. Consequently, these internal security challenges have not only posed threats to corporate existence of Nigeria as a sovereign state, but also undermined the quest for unity in diversity which underscores the rationale for adoption of federalism in Nigeria.

Thus, several internal security policies formulated by government appeared impotent to address the above security problems. This is partly because; policy makers appeared to have formulated such policies without considering the dynamic 
nature of violence, crime and security threats, especially in a heterogeneous society like Nigeria. However, policy makers failed to acknowledge that the achievement of desired internal security will be an exercise in futility when government lacks political will to foster socio-economic development in the state. However, an overview of specific internal security problems in Nigeria provides useful insights to understanding the problems that confronted internal security policies and implementation failures in Nigeria's social formation. Against this background, this paper attempts a critical discourse of the Nigeria's predicament in handling internal security challenges in the $21^{\text {st }}$ century. The paper seeks to expose several systemic and institutional factors militating against effective implementation of the internal security policies of Nigeria, which undoubtedly aimed at addressing pockets of crime, insecurity, internal threats and social unrest within the Nigeria's political environment.

\section{Objectives of National Security Policy of Nigeria and Implementation Framework}

National security is an interactive and integrative system consisting of the individual as the irreducible basic unit, who is connected both to the state and the international political system by way of civil society... the state is the strongest entity for the enhancement of national security issues, but is increasingly being challenged by civil society which demands a larger role....(Buzan, 1991:209).

According to the National Security Policy of Nigeria, the central pillar of the country's national security policy objective is the preservation of the safety of Nigerians at home and abroad and the protection of the sovereignty of the country as well as the integrity of her state (Bassey, 2011). Other specific objectives include:

To safeguard the sovereignty, independence and territorial integrity of the Nigerian State;

To defend the African unity and independence;

Non-intervention in the internal affairs of other states;

Involvement in regional economic development and security cooperation and;

Attainment of military self-sufficiency and regional leadership.

The achievement of the above policy objectives in Nigeria have continued to pose serious challenges by the government. These objectives not only require strong political commitment by the government, but also the determination of Nigerian citizens. Thus, the achievement of the internal dimension of the Nigeria's nation security objectives has remained elusive despite several strategies and implementation framework adopted by the government. However, Nigeria has persistently been faced with several threats to her internal security. As Bassey rightly notes, the internal threats are those issues that distort the socio-political and economic balance of the nation (Bassey, 2011). These include:

Ethnic and religious militias which are well-armed and semi-trained to carry-out raids, ambushes and even assault against law-abiding citizens.

Inter-border and inter-communal conflicts.

Unemployment, especially among the youths with subversive and criminal behaviours leading to economic sabotage and threatening of civil economic installation, especially in the oil sector.

Consequently, while it is the traditional role of the military to check external aggression against the state, the army is implicitly relevant in monitoring the activities of various actors in the domestic sphere that manifestly pose danger to the society (Bassey, 2011; Eminue, 2006). In internal security management, such as the protection of lives and property of citizens in Nigeria, the role of the Nigerian Police Force (NPF), is obviously relevant and indispensible. The NPF performs conventional police functions and is responsible for internal security generally. This includes supporting the Prisons, Immigration and Customs; and performing military duties within and outside Nigeria as directed (NPF Public Relation Department, 2011).

Thus, available evidence shows that the Nigerian Police Force (NPF) has been incapacitated in tackling the increasing rate of internal security challenges in Nigeria since the return of democratic government in 1999. According to the Public Relation Department of the organization, NPF experiences endemic problems with retirement, training, inefficiency and indiscipline. According to Police Public Relations Department (PPRD, 2011), the Force lacks expertise in specialized fields. Further, the 
Force is challenged with corruption and dishonesty and these engenders low level confidence on the institution. Thus, crime prevention, detention and investigation are compounded by failure of the Force to report crimes accurately (Nigerian Police Watch, 2011).

The above systematic challenges of the NPF to effectively implement internal security policy of Nigeria are further exacerbated by poor institutional capacity of the institution in terms of manpower and logistics. Thus, available statistics shows that the staff strength of the Nigerian Police Force as at 2011 was estimated at 371,000 . Thus, this figure is grossly low considering Nigeria's national population which is about 164,000 as at 2011. This statistics implies that one Police Officer is expected to police or monitor the activities of 442 Nigerians in view of the ratio of 1:442. This pathetic situation did not improve between 2012-2016.

Comparatively, the statistics of the manpower capacity of some neighbouring countries like the South African Police Service (SAPS) is far better than that of Nigeria. With a national population of 49, 320, 500 as at 2009, the staff strength of South African Police Service was 189, 546. This means that one Police Officer is, therfore, expected to monitor or police 260 residents thereby giving a ratio of 1:260. (SAPSR, 2011). However, the inadequacies of the police institution to effectively tackle violent crimes including terrorism, ultimately resulted to the involvement of the Armed Forces of the Federal Republic of Nigeria in internal security governance. The Nigerian Armed Forces (NAF) is made up of the Nigerian Armey, Nigerian Navy, Nigerian Air Force and the Nigerian Police force. Thus, the personnel-strength of the Nigerian Armed Forces has remained a critical challenge to internal security policy implementation in Nigeria. As a country with pervasive cases of internal insecurity, the capacity of Nigeria's Armed Forces in terms of personnel strength, funding, sophisticated equipment, deployment and rapid emergency response, are grossly low (Aliyu, 2011).

Another critical issue of note is the budgetary allocation to Defense Sector in Nigeria. In the last ten years, analysis of Nigeria's Defense Allocation indicates lack of political will on the part of the Federal Government to address internal security challenges confronting the country. This is evidenced from the allocation made by the Federal Government to the sector, between 2008-2016.

It is imperative to note that Nigeria has several security formations (military and paramilitary), that participate in internal security management. To respond to the challenges posed by insecurity in the country, policy makers claimed to have adopted integrated security approach and this led to the establishment of Joint task Force (JTF). The security formations or agencies whose roles are critical to internal security policy implementation in Nigeria include; the Nigeria Army, Navy, Air force, the Nigerian Police Force, Nigerian Prison Service, Nigerian Immigration Services, Nigerian Security and Civil Defense Corps, Nigerian Custom Service, State Security Services and National Drug Laws Enforcement Agency.

However, the strategies adopted to implement the national security policy objectives of Nigeria appear impotent to address plethora of internal security challenges facing the country. The current conception of the Nigeria's internal security which is an integral part of the overall national security frameworks is at best state-centric and society-centered. As some leaders have argued, the ultimate goal of addressing the internal threats and challenges facing Nigeria is not just to safeguard the lives of the common man, but to protect the lives and the loots of the ruling class (Fayemi. 2003).

Thus, between 2001-2018, the Nigerian state witnessed several security challenges from her internal political environment. These challenges as some observers argue may be due largely to poor implementation strategies adopted by the government and her security appointees to tackle the country's internal security challenges. Hence, Akinterinwa (2001:11) puts the generational roots of the above problem in clear perspectives:

...security appointees have failed the President, Chief Olusegun Obasanjo. If we are to judge by the current state of lawlessness...it is a shame when the Attorney General gets killed so easily. The aggressive posturing Odua People's Congress, robbery, drug trafficking, advanced free fraud (419), unemployment, high price of commodities.. are realities being faced in the country that requires remedies...

The above observation underscores the relevance of effective policy strategy to implement the country's internal security policy. This observation reinforces the argument by Dye who insists that:

Implementation is the continuation of politics by other means...policy making does not end with the making of new law...and its signing by the president. Implementation involves all the activities designed to carry out the policies enacted by the 
legislative branch. The activities include the creation of new organizations, departments, agencies, bureaus, and so on...(Dye, 1972:312).

The above argument by Dye further reinforces the assertion by some scholars and analysts that the internal security policy of Nigeria abysmally failed to take cognizance of the "unusual suspects" or what Nnoli refers to as "the real enemies of the people" (Nnoli, 2006:10). The "unusual suspects" or "real enemies of the people" which revolve around the economic misfortune of Nigeria include poverty, inequality, unemployment, low per capita income, among others. The 'unusual suspects' encompasses politics, which is a reflection of aberrant behaviours of the ruling class such as nepotism, sectionalism, election rigging, bad governance, corruption, thuggery, hooliganism, among others.

The implementation framework to achieve the national security policy objectives of Nigeria undoubtedly neglected the role of domestic (internal) factors capable of affecting effective implementation framework. Also, the implementation framework equally neglected the fact that domestic or internal factors could lead to conflicts and this can subsequently metamorphosed to security challenges in the country. The above assertion is true because as Bassey rightly explains:

...containment or management of conflict entails an understanding of its nature before we can deal effectively with it intellectually, emotionally and behaviourally.. .structural analysis of conflict, violence and warfare focus on how the organization of the society shape action... (Bassey 2007: 62)

The inability of the implementation framework of the national security to reduce the vulnerability of the citizens of Nigerian obviously compounded the internal security situation in the country, especially since the return of democracy in 1999. Ultimately, these challenges require paradigm shift which some scholars have recommended to the government in the past. This paradigm shift may be akin to the continuous call for adoption of integrative approach in the formulation and implementation of national security policy objectives of African states. This appears to be the global trend in security governance by modern states which appears elusive in many African states, especially Nigeria.

\section{Nigeria and internal security challenges: A Historical Exploration}

Nigeria as a sovereign state has witnessed several plethora of challenges emanating from her internal political environment. The country has been under siege for some years largely due to militancy, and act of terrorism perpetuated by some individuals against the state. However, the most serious security challenges witnessed in Nigeria between 2001-2018 include; Niger Delta crises, kidnapping, Jos crises, Boko Haram crises and crises by Fulani Herdsmen. These threat perceptions are further elucidated below:

\section{The Niger Delta crises:}

The Niger Delta crises in the South-South region of Nigeria have long historic antecedence. Thus, during the colonial period, the areas hitherto referred to as Niger Delta were part of the Eastern region of Nigeria which came into being in 1951 (one of the three regions and later one of the four regions). This region comprises of several ethnic groups. They include, the people from colonial Calabar and Ogoja divisions which are the present Ogoja, Annang, Ibibio, Oron, the Efik, ljaw and Igbo as majority. However, the National Council of Nigeria and Cameroon (NCNC) was the ruling party in the region (Niger Delta Archive of News, 2011). Indeed, the NCNC later become National Congress of Nigerian citizens shortly after Western Cameroon decided to separate from Nigeria. Thus, the ruling party of Eastern Nigeria did not seek to preclude the separation but encouraged it. The Niger Delta is a very densely populated region and is sometimes called Oil Rivers. This is because, the area was once a major producer of Oil. However, the area was British Oil River protectorate from 1885 until 1893 when it was expanded and become the Niger Coast Protectorate (Niger Delta Development Commission, 2010).

The Niger Delta as now defined officially by the Nigerian Government extends about $70,000 \mathrm{~km}^{2}$ and makes up $7.5 \%$ Nigeria's land mass. Historically and cartographically, it consists of present day Bayelsa, Delta and Rivers States. In 2000, Obasanjo's regime included Abia, Akwa-lbom, Cross River, Edo, Imo and Ondo states to the region (Dafinone, 2008). The region comprises of about 31 million people of more than 50 ethnic groups. They include the Bini, Efik, Ibibio, Annang, Oron, ljaw, Itsekiri, Isoko, Urhobo, Ukwaani, Kalagbari and several others. The linkage between resource and conflict is exemplified in the Niger Delta region of Nigeria. Thus, the region is richly endowed with crude oil deposits, both in onshore and offshore. This has made the region the center of international controversy over devastating pollution, ecocide, kleptocracy and human right violation, in which the Royal Dutch Shell has severally been implicated (Mathiason, 2009). 
Admittedly, before the discovery of oil in 1956, the main-stay of local economy of the people in the region was fishing and farming. These occupations have been dislocated by oil exploitation and exploration. This pathetic situation partly explains factors responsible for perennial conflicts and crises over oil resources in Niger Delta. However, some observers (Terminiski, 2003; Akpan, 2011; Wale, 2009; Andrew, 2009), have bluntly argued that the role of oil in conflicts and crises in Niger Delta is paradoxical. This is because, while the multinational oil companies and the Nigerian state enjoyed the revenue accruing from oil exploitation, the communities in the Niger Delta were persuaded to endure its consequences such as spillage, gas flaring and several forms of ecological disasters (Ayodele \& Sotola, 2008; Akpan, 2011). This assertion is further corroborated by Idoko who posits that:

...the state is scarcely concerned about the prospects of good life for the people of the Niger Delta, neither is the state really interested in enduring peace and development of the region...there is no doubt that the Nigerian state has always believed in the use of force to reign on "trouble makers" in the Niger Delta which makes it less surprising that the federal government.. .maintains an occupation force within the Niger Delta territory...(Idoko, 2008:18).

The implication of the ecological problems posed by oil exploitation on the lives and economy of the people coerced many communities, non-state actors and most recently militia groups to protest against the federal government and the multinational oil companies operating in the regions (Oladesu, 2008). They used both constitutional means to draw attention to injustice of successive government to the plights of the regions since 1960.

In response, government resorted to the adoption of repressive policy and the sinister tactics of playing one community against other rather than addressing the problems facing the people (Akpan, 2011). This was a deliberate approach of instigated and intensified inter and intra-communal conflicts in the Niger Delta region (Human Right Watch, 2002). Thus, the use of force by the federal government of Nigeria to address a clear case of injustice and marginalization of the people was at its climax following the extrajudicial killing of Ken Saro-Wiwa and nine Ogoni leaders by the Abacha regime (Obodo, 2010). Thus, this singular action by Abacha's administration was condemned not only by some Nigerians, but also the international community. Consequently, the international community expressed her disapproval by imposing several sanctions on the Nigerian state during the period.

Indeed, the inability of the Federal Government, especially during the military era. to address the root causes of agitation (environmental problems, poverty, unemployment, inequality, lack of basic amenities, etc), in the Niger Delta region, resulted to proliferation of armed militia groups causing tension and militarization of nearly the entire region. This movement was superheaded by Movement for the Survival of the Ogoni People (MOSOP), founded by Ken Saro-Wiwa.

As Human Right Watch (2002) further pointed out, the agitation continued without reasonable policy action by the government until the Odi massacre of 1999. This extra-judicial action by Obasanjo-led administration claimed the lives of over 10, 000 people including women and children according to unofficial sources. This ugly incidence happened barely five years after the execution of Environmental and Minority Right Activist, Ken-Saro-Wiwa and 9 others. Thus, Saro-Wiwa and his kinsmen were killed, following their alleged role in the killing of four Ogoni Chiefs. The alleged action by Saro-Wiwa and his group was based on their conviction that those four Ogoni Chiefs were collaborating with the government and Shell to subvert their efforts toward addressing the fundamental issues such as neglect, marginalization and injustice (Aderoju, 2008). The hardship the above social malaise has caused to the lives of an average Niger Delta indigene is put to perspective by Mitee who explains that:

The fundamental problem of the Niger Delta still remains the challenge posed by the very harsh environment which made development most challenging and resulted in the criminal development neglect of the region... (Mitee, 2009:15).

The trajectory of the crisis in Niger delta is understandable from the point of view of the inability of the Government to provide basic amenities and infrastructural development for the people. This sorry situation is compounded by the economic dislocation occasioned by the oil exploitation and exploration activities in the region. Thus, it is the politicization of these issues that culminated into struggle for resource control and subsequent militancy in the Niger Delta region (Amaizu, 2008). This point is well articulated in the Ogoni Bill of Rights, the Kaima Declaration and other protest documents as deliberate struggle to compel government to address the perceived neglect and poor condition of the Niger Delta people.

However, several intervention institutions and programmes initiated and implemented by the government such as the Oil Mineral Producing Area Development Commission (OMPADEC) and Niger Delta Development Commission (NDDC), to address the problem of the Niger Delta undoubtedly performed below expectations. Consequently, the abysmal failures of 
these institutional mechanisms established to douse tension in the region coerced the government to resort to other measures to bring enduring peace in the region. This was after several loss of revenues by the Federal Government from the oil sector. The loss of resources that amounted to billions of naira was largely due to the activities of the militants who forced oil companies to close down and increasing spate of kidnapping of expatriate oil workers in the region. These armed militias and anarchic group also engaged in illegal bunkering of oil resources and destruction of oil installations in the region. Consequently, these illegal actions grossly reduced Federal Government's revenue from oil sector, especially between 1999 and 2015.

The ugly development in the Niger Delta which adversely impacted on the Nigeria's economy ultimately became a source of worry. Hence, the Federal Government decisively adopted another policy measure to reduce the spate of insecurity in the region. This decision resulted to the application of minimal force to ensure that militants drop their crimes and hostilities against the government and the people of the region.

Towards the end of 2008, the Federal Government launched a massive military crackdown on militants (Amaizu. 2008). Thus, the military patrolled waterways, hunted for militants, searched all civilian boats for weapons and raided numerous hideouts in the region. Also, on May 15, 2009 (the following year), a military operations undertaken by the Joint Task Force (JTF), was put in place by the federal government against members of the movement for emancipation of Niger Delta (MEND), and their affiliates in the region (Onoyume, 2008).

Paradoxically, rather than these measures to address the challenges of internal security in the Niger Delta, the situation led to incessant kidnapping of not only the foreign oil workers, but also the indigenes and other residents in the region. In view of the worsening security situation in the region, the Federal Government adopted another civil and tactful approach in resolving the poor security internal situation in the Niger Delta. Thus, on June 26, 2009, the federal government under the leadership of Late President Umaru Yar' Adua, announced the granting of Amnesty and unconditional pardon to militants in the Niger Delta (Rotimi, 2009). However, the militants were given between August 6, to October 4, 2009 to surrender their weapons to the Federal Government in return for training and rehabilitation.

Hence, during the 60 days period, the militants led their groups to surrender their weapons which included rocket-propelled grenades, guns, explosives, ammunitions, gunboats, among others. This strategy adopted to end hostilities in Niger Delta by the Federal Government, significantly increased Nigeria's oil production and consequently enhanced Federal Government's revenue from oil sector between 2009-2011.

Thus, as Nigeria witnessed a change in her political equation which resulted to the opposition party (All Progressive Congress, APC) controlling the Federal Government in 2015 General Election, the crises in the Niger Delta took a different dimension in Nigeria. This time, a militant group known as Niger Delta Avengers commenced the destruction of government economic outfits in the Niger Delta Region. This resulted to a sharp drop in oil production and its attendant consequences on revenue accruable to the Federation Account.

However, despite several mediation efforts of prominent Nigerians from other parts of the country and indigenes of the Niger Delta region, the Niger Delta Avengers has continued to destroy oil installations belonging to leading oil companies such as Mobil, Shell, Total, Agip, among others. The implication is that the hostilities in the region ultimately forced many oil firms to shut-down in the Niger Delta region of Nigeria. This pathetic situation has continued to affect the economy of the Nigerian state adversely.

\section{(ii) Kidnapping in the South-East Zone of Nigeria}

Kidnapping is one of the criminal activities that have continued to pose serious security threat to the Nigerian State. According to Chukwurah (2011), kidnapping is conceived as the act of illegally taking someone away and keeping him as a prisoner for the purpose of receiving ransom (money in return). Historically, kidnapping in the South-East zone and some other parts of Nigeria, could be traced to the hostilities, conflicts, crises and violence in the Niger Delta region (Igbokwe, 2009).

The challenges posed by this criminal dimension of Nigeria's perennial internal security checklist painted negative image of the country nationally and internationally. This ugly situation explains why Arizona-Ogwu, a Nigerian Residing in the United States of America bluntly describes the attitudes of the Federal Government of Nigeria toward the menace of crime as follows: 
Owing to the government cold-feet attitude to certain crimes in Nigeria, there is an outcome of thousands of cases signifying the brutality wrought on the innocent Nigerians with the help of local collaborators. Besides kidnappings and murders, there are millions of cases of torture, rape, arson, looting and other crimes (Arizona-Ogwu, 2010:18)

In the South-East geo-political zone of Nigeria, kidnapping activities were initially targeted at prominent indigenes and residents of the region. The incidence of kidnapping became more pervasive shortly after the 2007 General Elections in the country. This is partly because, the youths who were used as political thugs by some inordinate politicians during the 2007 General Elections subsequently engaged in kidnapping as a means of livelihood after the elections (Nwosu, 2011). The violent nature of kidnapping and its socio-economic implication on the economy of the South-East zone of Nigeria are enormous.

Specifically, the menace of kidnapping was phenomenal in Abia State, especially in Aba metropolis and its environs. This criminal activity brought tension in the commercial city and compelled many families to abandon their residence (Eke, 2011). Besides individuals and families that ran away from Aba metropolis for security reasons, some manufacturing companies relocated to peaceful states like Enugu, Anambra and Ebonyi for their businesses. This ugly incidence adversely impacted on the economy of Abia State, in particular and Nigeria in general (Akinrinade, 2011). This situation further resulted to loss of jobs by some residents of Aba metropolis, thereby increasing unemployment rate in Abia State particularly and Nigeria generally.

Besides the relocation of these major manufacturing companies to more peaceful states, some small and medium scale business operators ran away from Aba and its environs due largely to high incidence of kidnapping. Thus, the increasing rate of this menace also resulted in several foiled attempts to kidnap the former Executive Governor of Abia State, Chief Theodore Orji in 2008 (Nwogu, 2008). From 2008-2010, several prominent men and women in Aba, as well as its environs were kidnapped for ransom. This includes political office-holders in Abia State, Traditional Rulers, business-men and women, civil and public servants. This pathetic situation impacted negatively on the economy of Abia State. Similarly, the Nigeria Gross Domestic Product (GPD) and Foreign Direct Investment (FDI) of Nigeria were grossly affected, thereby resulting to unemployment, poverty and their attendance implications.

The menace of kidnapping in Abia State got to a crescendo when some school children were kidnapped in Aba in 2010. However, this singular act and consequent kidnapping of "common man" compelled all the commercial banks in Aba metropolis to shut-down for several days. However, prior to this decisive action by the banks, many of them had been repeatedly robbed by armed gunmen in Aba, which is the commercial nerve centre of Abia State.

Worse still, kidnapping in the South-East geo-political zone also impacted negatively on social relations as some people were kidnapped during church services, village/town hall meetings and at market square. This resulted to the decisions of some illustrious sons and daughters of many rural communities from the zone to stay away from their villages during the Christmas and festive periods (Soriwci, 2011). The implication of this was that the rural dwellers could not speak with 'one voice' on community development programmes, let alone repose confidence on one another. They were suspicious of each other and could not come together as a people to articulate development programmes for the general well-being of their areas.

To redress the challenges posed by kidnapping in the South-East geo-political zone, the Federal Government of Nigeria, on passionate request of the Abia State Government, deployed soldiers to Aba metropolis. Thus, Okoli (2009:27) shades more light to the above bold step by the government.

...Governor Theodore Orji of Abia State formally invited the Army to the state to assist in the fight against crime and criminals, especially kidnappers. The Governor said the menace of kidnapping seemed to have overwhelmed the police...

Consequently, the action of government in mobilizing the Army to flush "kidnappers" in Aba and its environs minimized the reported cases of this menace in the area. This was largely due to intensive attacks launched by the Army at the identified hideouts of "kidnappers" in Ukwa-West Local Government Area of Abia State (Sampson, 2010).

It is imperative to note that several other criminal activities also threatened the security and economy of the South-East geo-political zone in particular and Nigeria in general during the reviewed period. Such criminal activities include murder, rape, ritual killings, robbery, human trafficking, politically-motivated killings and assassination of prominent men and women 
in the zone (Ajani, 2010). Thus, the above criminal activities may have impacted negatively not only on Nigeria's Gross Domestic Product (GPD), but also crippled most economic activities in the South-East geo-political zone (Agboso, 2011).

However, despite kidnapping which undoubtedly crippled the economy of the South-East geo-political zone particularly and Nigeria generally, the agitation for self-rule or Sovereign State by the indigenous People of Biafra (IPOB), also threatened internal security governance of Nigeria. The agitation was geared towards the realization of the Sovereign State of Biafra. This agitation was championed by Mr. Nnamdi Kanu (an indigene of Afara in Umuahia, Abia State)

Indeed, the agitation for the realization of Republic of Biafra also has long historic origin. Thus, the quest for self government by the old Southern Region of Nigeria, comprising States in the current South-South geopolitical zones of Nigeria such as Cross River, Akwa lbom, Rivers, Delta, Bayelsa and Edo States, as well as some states currently in the Middle Belt region like Kogi and Benue, was precisely what resulted to Nigerian Civil War between 1967-1970.

In response to this agitation, the Federal Government headed by Major General Mohammadu Buhari (Rtd), arrested the Leader of Indigenous People of Biafra-Mr. Nnamdi Kanu. Thus, Mr. Kanu was prosecuted for treason felony. The members of IPOB declared that the only remedy to their agitation is simply for the Nigerian Government to allow Biafrans to gain independence. This situation adversely impacted an internal security posture of the Nigerian State during the period under review.

\section{(iii) Jos Crisis}

The Jos crisis is another internal security threat which appears difficult for the internal security policy of Nigeria to address in recent times. The Jos crisis is a combination of the violence that followed the November, 2008 Jos North Local Government election (Audu, 2011). Historically, Jos is the capital of Plateau State of Nigeria. The city of Jos has witnessed several sectarian, ethnic and political clashes among which were the September, 2011 and April 2004 conflicts that resulted to the imposition of state of emergency on Plateau State by the Obasanjo's administration.

However, the violent dispute as argued by some observers is over the "rights" of the indigene ofBerom/Anaguta/Afizere (BAA) group and the rival claims of the Hausa-Fulani settlers to land, power and resources (Nakande, 2011). To some analysts, the immediate and remote causes of Jos crisis prior to November, 2008 crisis has been politicized along sectarian and ethnic lines (Akpan, 2011). Those inclined to the ethnic thesis believe that the crisis is a classic case of ethnic cleansing. They further argued that the Berom, Anaguta, Afizere and the Hausa/Fulani, laying claim to pre-eminence over one another is the main cause of the crisis in Jos (Akpan, 2011).

The above position is further supported by the crisis group report on Jos crisis. According to the report:

Indigene - settler conflicts are not new to Nigeria... the Jos crisis is the result of failure to amend the constitution to privilege broad-based citizenship over exclusive indigene status and ensure that residency rather than indigenity determines citizen's rights.. .constitutional change is an important step to diffuse indigene-settler rivalries that continue to undermine security... (Crisis Group Report, 2011:21).

Thus, the indigene principle or indigenity (that is local origin), means that some groups control power and resources in the state or local government area, while others, particularly those assumed to have migrated for different reasons are completely excluded. This situation gives rise to both grievances and fierce political competition which too often lead to interference, agitation, conflicts, violence and internal security challenges in Jos. The Jos crisis which has attracted mixed reactions from both local and international observers mostly occurred in some local government areas.

The ugly and annoying posture of the federal and state governments in resolving the problem in Jos have further attracted mixed reactions from Nigerian citizens and international community. As Human Right Watch Report rightly observed:

...the discriminatory policies lies at the root of much of the inter-communal violence in Nigeria... with these policies, nonindigenes are openly denied the right to compete for government jobs and academic scholarships...in Jos, Kuru and Karama, members of the largely Muslim Hausa ethnic groups are classified as non-indigenes though may have lived there for several generations... government should take concrete steps to end the discriminatory policies that treat certain groups as second-class citizens... (Human Right Watch Report, 2010:29) 
Specifically, the unresolved crisis in Jos has claimed numerous lives of Nigerians and property worth billions of naira, particularly between 2001 to 2018. The crisis which seems to have defied all manner of intervention by the Federal and State Governments, as well as the Non-Governmental Organizations (NGOs), have resulted in frequent attacks on Christians by some Muslims (Obateru \& Omonobi, 2010). Indeed, between 2001-2011, over 10, 000 Christians were slaughtered during the Jos crises. In 2010 crisis for instance, about 500 Christians lost their lives (Oladonyinbo, 2010). Similarly, some Muslims equally lost their lives during the crisis.

Indeed, the Jos crisis has resulted to unimaginable confrontations, killings, bombings and other forms of violence on the residents. The magnitude and wanton destruction of lives and property partly explains why the Late Terror Master - Gaddafi of Libya, once suggested that Nigeria should be divided into two religious lines (Muslim and Christian states). This suggestion was in consideration of frequent attacks on Christians by Muslim community. This pathetic situation as Sunday Tribune Editorial rightly noted was as a result in the emergence of a group known as Islamic Assailants. This group has continued to cause tension in Jos, displacing Nigerians and setting houses and property of the people ablaze. The Editorial Report further explains:

Jos, conflict seems to reoccur in every narrowing cycles... deadly riots rocked the city in 1994-2001, 2008 and two months ago... in January 2010. The current conflict is said to have started in reappraisal for the destruction that occurred in January... there has been reports of children and the elderly being particularly targeted by roving gangs armed with guns and machetes... (The Editorial Report of Sunday Tribune Newspaper, 2011:2).

Admittedly, the Jos crisis have raised serious question on the unity and development of Nigeria. Thus, available evidence has shown that the crisis in Jos has been fought on sectarian lines and this ugly trend is traceable to 'sour relationship' between the Christian and Muslim communities in some parts of Plateau State. The understanding of this relationship is pertinent because, as Human Right Watch Report Watch -Report rightly argues:

...Jos lies on the border between Nigeria's Muslim minority North and Christian majority South. Access to land resources is often determined by whether one is a native or indigene... Jos is historically Christian city... settlers are most often Muslims from the North... (Human Right Watch Report, July 10, 2010:20)

The above observation by Human Right Watch reinforces the result of some studies on Jos crisis. According to crisis group, the problem in Jos borders on citizenships status. The Crisis Group bluntly argues that:

because the settlers are almost entirely Muslim and the indigenous people are predominantly Christians, struggle over land ownership, economic resources and political control tend to be expressed not just in ethnic but also religious terms... since 2010, security has further deteriorated in Jos because of terror attacks and suicide bombings against churches and security targets by suspected militants of Boko Haram... the Islamic group is responsible for an unprecedented wave of terrorist attacks in the North... (Crisis Group: Africa Report No. 196, 2011:14).

From the above premise, it becomes imperative to rhetorically query why the Federal Government of Nigeria appears reluctant to tackle the root causes of the problem in Jos and to prosecute those perpetrating these dastardly crimes in the area?. Also, why has the Federal government perpetually kept quiet in addressing the problem of citizenship within the Nigerian political space? Why has the Federal Government and Plateau State abysmally failed to implement the recommendations of several committees set-up to find lasting solutions to the crises in Jos? Thus, the reaction of Hilary Clinton, the former US Secretary of State, provides useful insights to credible answers to the above questions. Thus, Hilary Clinton fearlessly argues that:

...the Nigerian political leaders failed to live by- examples, thereby increasing the radicalization of many young Nigerians... fierce and unregulated political competition characterized by ethnic mobilization and violence, coupled with poor governance and rampant corruption, have severally exacerbated ethnic, religious and regional fault lines (Crisis Group Report, No. 196, 2011:14).

Therefore, it is strongly argued by some analysts that the Jos crises require both national and local solutions. Thus, constitutional provisions by virtue of their ambiguity over terms such as "indigene" (which the amended 1999 Constitution of the Federal Republic of Nigeria failed to define satisfactorily), and "residency" for accessing citizenship rights, have done little to clarify the situation. Hence, Nigeria's current implementation of its citizenship (or national) question appears to be grossly inadequate and flawed. This situation as some analysts have rightly argued requires the collaboration and political 
will of both the executive and legislative arms of government at the national level, especially to articulate implementable policy strategies to resolve the problems in Jos.

\section{iv)Boko Haram Crises}

... what is going on is a new phase in this nation. Neither Nigerians, the government nor the security agencies is used to a situation where innocent citizens will be attacked for a cause that is clearly difficult to reason with or to explain...the Islamic fundamentalist group has claimed responsibility for attacks on government and private institutions, including the suicide bombings of the Police Headquarters and the United Nations (UN) House in Abuja... many people were killed in these attacks (Ojiabor, 2011:10; quoting the former Minister of Information in Nigeria, Hon Labaran Maku).

The activities of Boko Haram as a terrorist group in Nigeria has been described in several ways by public analysts and observers. To some, Boko Haram is simply a group of people committed to the propagation of the Prophet Muhammed's teachings and Jihad in Nigeria. To others, Boko Haram is a socio-political fundamentalist group that rejects western education and culture. Also, others see this group as Islamic movement which strongly opposes man-made laws. However Boko Haram is conceptualized, available evidence indicates that it is Muslim sect that seeks to abolish the secularity of the Nigerian State and establish Sharia Law in Nigeria (Alaneme, 2011).

Etymologically, the term 'Boko Haram' is derived from Hausa word 'Boko' meaning 'Animist; Western, otherwise non-Islamic education; and the Arabic word 'Haram' figuratively meaning 'sin' or literally forbidding' (Olugbode, 2010). The summary of the above descriptions is that Boko Haram as a terrorist group abhors western education, culture and the general behaviours of Muslim faithfuls, especially the elites who promote western ethics. For this group, western education, culture, modem science and their related-terms, are not only forbidding, but also sacrilege (Dunia, 2010). Comically, the group asserts that the belief that the world is 'spheral' or 'ovat in shape is contrary to Islam and should be rejected along "Darwinism evolution theory" which asserts that rain comes from water evaporated by sun.

Historically, the Boko Haram group was founded in 2002 in Maiduguri by Utaz Mohammed Yusuf (Ikuomola, 2011). In 2004, this terrorist group moved to Kanamma in Yobe, where it sets up a base called 'Afghanistan', The 'Afghanistan' therefore, became the group's base to lunch terror and frequent attack on near-by police outposts and killings of police officers (Awowole, 2010). However, the founder of this terrorist group (Utaz Mohammed Yusuf), was hostile to democracy and secular education system operative in Nigeria and supported by some Northern elites. This partly explains why he vowed that the war he began in 2002 would ultimately change the political, economic and educational systems in Nigeria; a dream not realized till his gruesome death in 2009.

The Boko Haram does not mix with the local people in the Northern part of Nigeria. Thus, Available literatures have demonstrated that lot of members of this terrorist group that speak Arabic come from neighbouring Chad (Ojiabor, 2011; Obi, 2011; Anofi, 2010). This undoubtedly is as a result of the group's strong belief in the Koranic phrase which says "Anyone who is not governed by what Allah has revealed is among the transgressors". Thus, whether western education which majority of elites from the Northern Nigeria have acquired was not revealed by the "Allah' is entirely a subject hotly debated in Nigeria's political space. Consequently, the Boko Haram terrorist group has launched several attacks against the Nigerian State.

However, the magnitude and severity of the attacks by Boko Haram terrorist group are greater in some states/cities than others in the same Northern part of Nigeria. According to Champion Newspaper Report of June 12, 2011, it is estimated that Borno State records the highest rate of casualties $(2,400)$, Yobe $(1,950)$, Adamawa $(1,720)$, Bauchi $(1,500)$, FCT Abuja $(1,510)$, Kaduna $(1,230)$, Plateau $(1,200)$, Kano (850), Niger $(520)$. This is further explained in Fig. 2 below: 
States/Cities in Northern Nigeria with high rate of attacks by Boko Haram

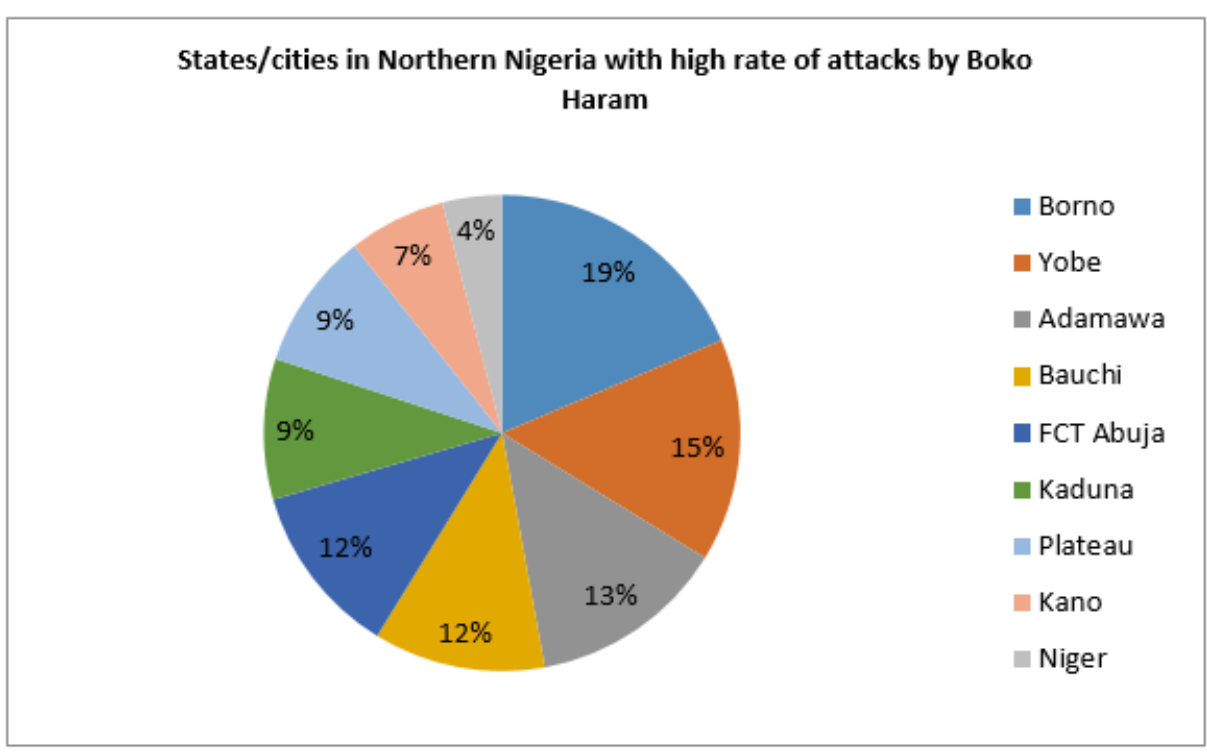

Fig 2: States/cities in the Northern part of Nigeria with high rate of attacks from Boko Haram terrorist group. Source: Champion Newspaper, June 12, 2011.

From fig. 2 above, it is observed that the state that received the highest rate of terrorist attack from BokoHaram between 2009-2018 was Borno State. Similarly, the Borno State has continued to receive several attacks from this terrorist group, even after the death of the Boko Haram founder. Thus, the climax of this inhuman act was the adoption of over two hundred (200) Chibok Dapchi school girls in 2014 and 2017 respectively by Boko-Haram terrorist groups. The reason could be that the group was formed in Maiduguri which is the Borno State Capital. The next state that received severe attacks from this group as evidenced in fig. 2 above was Adamawa, followed by Yobe State, especially Damaturu. The reason could be as a result that Boko Haram moved from Maiduguri where it was formed to Yobe State where it established its operational base it named 'Afghanistan'. As stated earlier, it was from its operational base in Yobe State that it began to launch incessant attacks on police officers and police stations in the area. Thus, other states and cities in the North that received attacks from Boko Haram could simply be as a result of the arguments among observers that Boko Haram is a terrorist agenda of some groups from the North to pull down the secularity status of the Nigerian State.

It is pertinent to note that Boko Haram promotes a version of Islam which makes it 'haram' or forbidden for Muslims to participate in any political or social activities with Western States and their allies. This includes voting in election, wearing shirts and trousers or receiving a secular education (Ajayi, 2011). The activities of the Boko Haram terrorist group constitute serious security threats to effective implementation of the National Security Policy of Nigeria. Thus, between 20092018. This group has killed so many residents in Nigeria, destroyed property of both the government and citizens and subjected millions of Nigerians to IDP camps. The criminal activities of this group and their implications on the implementation of National Security Policy of Nigeria are put to clear perspectives by some scholars who bluntly argue that:

...the recent surge of the Boko Haram through series of bombings that have killed several innocent Nigerian citizens is a serious breach and challenge to national security. The bombing of the United Nations building in Abuja on Friday $26^{\text {th }}$ August, 2011, killing not less than 22 people and wounding scores of others has further demonstrated not only the wickedness of the group, ... these bombings are serious crimes against the Nigerian State and threaten national security... (Ekanem et al., 2011:33).

The activities of Boko Haram which has raised critical questions among investors on the safety of their investments in Nigeria range from killing of innocent Nigerians/residents, raping of women, to indiscriminate bombing of major cities, 
churches, police stations and public gatherings, especially in the northern parts of Nigeria. As some analysts argued, these criminal activities have not only gained Nigeria a poor image in international political arena, but also impacted negatively on the economy of the Nigerian State.

It is imperative to note that the Boko Haram group may have executed other terrorist attacks against the Nigerian State apart from those presented in this study. Also, some of the criminal attacks by the group against the Nigerian State and its citizens may not have been effectively reported to the public by the media. This situation makes it difficult to have accurate data of the activities of this anarchist movement against the Nigerian State and her citizens.

Beside the security challenges posed by Niger Delta crises, Jos crises, kidnapping in the South-East, Boko Haram terrorist group and crises by Fulani Herdsmen in some part of the Northern Nigeria, the Nigerian political space also witnessed other forms of security threats or what could best be described as criminality. Some of the security threats were violent in nature like the case of rape, armed robbery, ritual killing, murder, child stealing/baby factory making venture etc, while others like HIVIAIDS, Ebola, cholera, Lassa fever, etc were non-violent. These security threats appear to have adversely affected the Nigerian economy, the image of the country at the global arena and social relations among the Nigerian citizens. The magnitude and severity of these crimes differ sharply from major security challenges witnessed in Nigeria in recent times, such as Niger Delta crises, Jos crises, kidnapping, Boko Haram insurgency and Fulani Herdsmen crises. However, the magnitude, severity and concerns generated by some internal security challenges in Nigeria is represented in fig. 3 below:

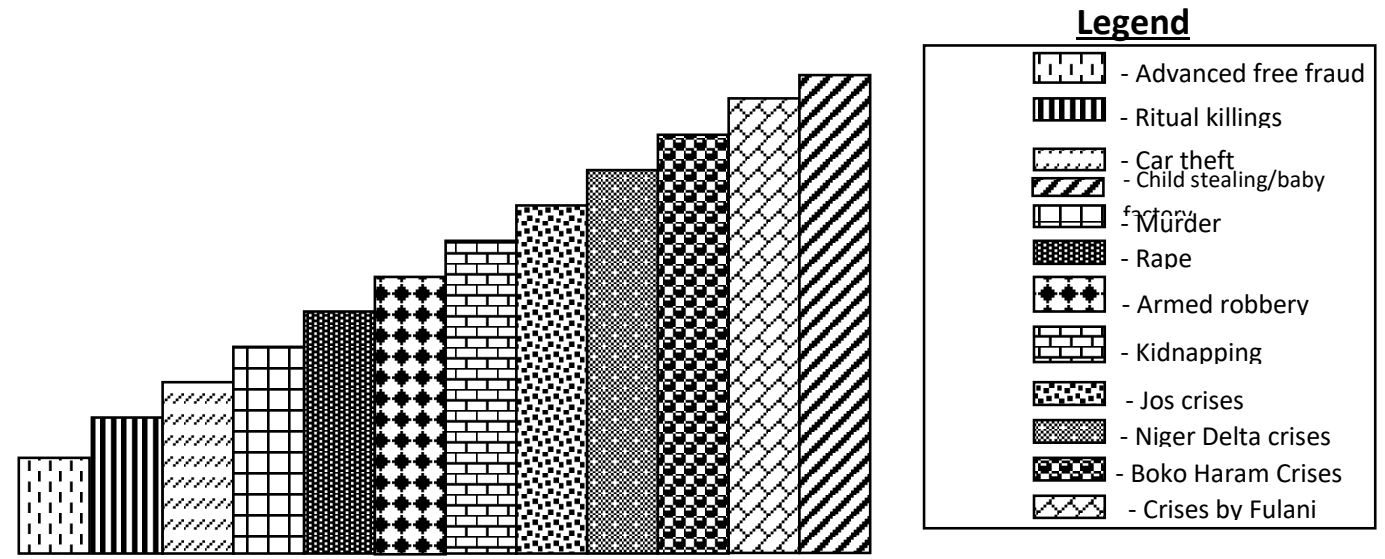

Fig. 3: Presentation of Minor and Major Internal Security Problems in Nigeria.

Source:Nwagboso's field survey, 2018.

From Fig. 3 above, it is evident that categories of crimes that posed threats to internal security governance of Nigeria. They are grouped as major and minor security threats in Nigeria. Thus, the minor security threats are criminalities that may have impacted only the economy of Nigeria.They include, rape, armed robbery, ritual killings, car theft, murder, child stealing/ 'baby factory making venture', advanced free fraud, among others. The major security threats are those that impact negatively on both the economy and statehood. They include, the Niger Delta crises, Jos crises, kidnapping, Boko Haram crises and crises by Fulani Herdsmen. However, the Jos crises and kidnapping are included in these categories as a result of their implication on the image of Nigeria in global politics.

\section{v. Crises by Fulani Herdsmen}

Recently, another ugly internal security challenge that currently perturbs the government and the people of Nigeria is the incessant mayhem launched by Fulani Herdsmen mostly in the Northern part of the country. Thus, "Fulani" is an ethnic nationality found in core northern states of Nigeria, such as Borno State, Kano, Jigawa, Bauchi, Zamfara, Yobe, Adamawa, Katsina, Sokoto, Gombe among others. Their traditional occupation prior to the current wave of globalization and western civilization is cattle rearing. Indeed, the 'Fulanis' usually move their cattles from one geographical location to another. 
However, available evidence shows that due to poorclimatic condition in the Northern Nigerian,which most often delays rainfall in the region, the 'Fulanis' move their cattles from the Northern part of Nigeria to Southern part of the country, especially during dry season (October to March).

This nomadic movement and its attendant implications as widely acknowledged by some Nigerians is occasioned by the fact that between October and March, the 'Fulanis' find it difficult to feed their cattles as grasses usually die during the period. Hence, they move to Southern part of the country in search of green pastures for their cattles. It is significant to note that the Fulanis move back to the Northern part of Nigeria during raining season.

Historically, Fulani Herdsmen usually encounter clashes with farmers in the Northern Nigeria due largely to destruction of their crops and farm lands by their cattles. On the other hand, the herdsmen often face severe challenges from cattle rustlers (armed cow thieves) who often launch attack from neighbouring countries like Niger Republic, Chads, Cameroon, among others.

However, both the crises from the perspective of Herdsmen- farmers and Herdsmen- cattle rustlers undoubtedly have long historic antecedence. There was never a time the clashes by Herdsmen and farmers as well as Herdsmen and cattle rustlers posed threat to the authority of the state and corporate existence of Nigeria as sovereign nation-state.

Recently, there appears to be a paradigm shift in threat perception and conceptualization of internal security challenges in the Northern part of Nigeria. This is because, what used to be a common internal security challenge in the region such as Herdsmen-farmer clashes and Herdsmen-cattle rustlers, have significantly metamorphosed into a more perturbing internal security challenge in the country. Consequently, available documented evidence has shown that in 2012, Herdsmen started to move around for grazing of the cattles with guns and ammunition and frequently launch attacks on civilian population (Aminu, et al, 2018). Indeed, such barbaric dispositions on civilian population, particularly farmers resulted in the destruction of lives and property ofmost communities in Benue, Kaduna, Zamfara, Borno, Yobe, Adamawa, Taraba, etc. Thus, between 2012 and 2014, the clashes between Herdsmen and farmers persisted and this resulted to most communities running away from their homes.

However, government responses to this ugly internal security situation in the Northern Nigeria were the establishment of Internally Displaced Persons (IDP) camps in most states ravaged by Herdsmen-farmers clashes. Also, government responded to this pathetic internal security situation by swift implementation of a critical component of welfare policy such as the distribution of relief materials to the Internally Displaced Persons (IDP) at various camps in the affected Northern States of Nigeria. Thus, such relief materials include food items, building materials, drugs and money among others. The menace of armed Herdsmen-farmers conflicts are mostly witnessed in the following Northern states as presented in table 1 below:

\section{Table 1: States in the Northern Nigeria mostly affected by Herdsmen-farmers crises}

\begin{tabular}{|l|l|l|}
\hline S/N & State & Geographical zone \\
\hline & Benue & North-Central \\
\hline & Kaduna & North-Central \\
\hline & Adamawa & North-East \\
\hline & Yobe & North-East \\
\hline & Taraba & North-East \\
\hline & Borno & North-East \\
\hline & Zamfara & North-West \\
\hline & Nassarawa & North-Central \\
\hline & Jigawa & North-West \\
\hline
\end{tabular}

Source: Nwagboso's field survey, 2018.

From table 1 above, the Herdsmen-farmers crises mostly affect states in the North-East geo-political zone of Nigeria. This is followed by the North Central and North-West. The reason why the North-West is mostly affected as some analysts have argued is duely largely to the long historic internal security challenges occasioned by the activities of the Boko Haram in the region (Obi, et al, 2018). In table 1, we found out that the barbaric activities of Herdsmen have spread to some other states in the North-Central, such as Benue, Nassarawa and Kaduna. Similarly, the dastardly acts exhibited by the Herdsmen became a source of worry to some states in the North-West such as Zamfara and Jigiwa. 
As a response to this new phase of internal security challenge in the Northern part of Nigeria, the Federal Government considered the enactment of Open Grazing Law. Thus, the Open Grazing Law seeks for the establishment of grazing areas in all parts of the Nigerian States.The aim is to ensure that state governments across the 36 states of the Nigerian Federation provide land for Fulani Herdsmen to move their cattles in those states and openly graze/feed them without hindrances.

Consequently, some advocates/proponents of this view (Open Grazing Bill), immediately sponsored a bill at the Nigerian Senate for possible passage into Law. This strategy by Buhari-led administration to clandestinely coerce State Governments in Nigeria to cede part of their territories for open grazing agenda in favour of Fulani Herdsmen (his kinsmen), was welcomed by few(State Governors from the Northern Nigeria. For instance, the Governors of Benue (Samuel Ortom) and Kogi State (Yahaya Bello) did not hesitate to accept the idea without considering its devastating implications on the internal security governance of their states, particularly and Nigeria generally. Paradoxically, Benue State is currently the worst hitherto devastated or destroyed by the dastardly acts of the Fulani Herdsmen.

Interestly, the Governor of Abia State, Okezie Victor Ikpeazu, Ph.D, did not hesitate to raise objection to Open Grazing view in Nigeria. This was after Dr. Ikpeazu had carried out empirical and scientific studies on the activities of Fulani Herdsmen in communities they have previously cohabited. Thus, several available documented evidencehas demonstrated thatFulani Herdsmen oftenengage in expansion agenda, ultimately aimed at driving away, their host communities wherever they are allow to live (Olaniyi \& Nzeagwu, 2018; Akor \& Iwok, 2018).

Indeed, the position and argument of the Governor of Abia State that the idea for the enactment of Open Grazing Lawby the Federal Government of Nigeria as welcomed by Governors Ortom of Benue and Yahaya Bello of Kogi States was later accepted by many State Governors in Nigeria as best option for the country. According to some State Governors, Governor Okezie Ikpeazu of Abia State was right in his arguments over objection to Federal Government's proposed Open Grazing Law. Thus, the supporters ofDr. Ikpeazu in this regardsuch as his colleagues from other states eminent Nigerians from academia, businessmen, traditional institutions, among others, increasingly resulted to stiff opposition by many Nigerians against passage of Open Grazing Bill into Law by the Nigerian Senate.

It is, therefore, pertinent to note that Benue State Governor, (Samuel earlier Ortom) who was the First Senate Governor in Nigeria to welcome the idea of Open Grazing Law, is currently at the fore-front criticizing the idea, working assiduously to suffocate any move or ploy to cede parts of Benue territory to Fulani Herdsmen for grazing venctures. This is largely due to the fact that his state (Benue) is deeply devastated by the menaces of Fulani Herdsmen.

Unfortunately, the 'farmers-herders' crises in the Northern part of Nigeria have taken pathetic and vexing dimension. The crises which have received condemnation from regional and international communities not only appear to be transnational, but also seems to be sponsored by foreign non-state actors. This is because, what some observers and analyst describe as "Killer Herdsmen" operate from Nigeria's immediate borders and other countries like Libya as recently asserted by the Nigerian President, His Excellency, Mohammadu Buhari. The mercenaries intrude into Nigeria from neighbouring countries such as Niger, Chad, Cameroon etc, attack defenseless communities, kill, maim and rush back to their base. From intellectual point of view, these mercenaries do not move with cows like the conventional Fulani Herdsmen that used to engage in conflicts with farmers in Northern States of Kebbi, Katsina, Bauchi, Sokoto, Yobe, Zamfara, among others.

To be sure, the crises between the farmers and herdsmen in the above states and many parts of the Northern Nigeria were largely due to the invasion of farmer's lands belonging to farms by the Herders. This behavioural pattern of Herders ultimately destroys crops and sometimes results to hunger in many parts of Nigeria in the subsequent year. Precisely, the current face-off between most communities in the Northern Nigeriaand the so-called killer Herdsmen is undoubtedly different from the traditional threat perceptionthat frequent occur between farmers and herdsmen in the northern partof Nigeria.

According to the Nigerian Watch Organization, the crises between farmers and Fulani Herdsmen/or Killer Herdsmen and rural communities in the Northern Nigeria has claimed about 14,000 lives in 2018 alone (Nigerian Watch Organization, 2018). This latest development in threat perception in Nigeria has raised different debates. To some, the crises between the killer herders and communities in the North are a continuation of Boko Haram onslaughts in the North-East Zone of the countries. This includes Borno, Yobe, Adamawa and Taraba. However, other analysts and observers argue that the crises in the Northern part of Nigeria are well planned, articulated, conscious and deliberate action, strategically aimed at wiping 
away some ethnic nationalities. This position issupported by the assertion by Former Military Leader and Minister for Defence, under Chief Olusegun Obasanjo's administration,Lt. Gen. T. Y. Danjuma. Recently, Danjuma categorically stated in press release that the current killings in Taraba State (his state of origin)and several other Northern part of Nigeria, is undoubtedly an "ethnic cleansing", systematically aimed at 'wiping out' particular ethnic groups in Nigeria. The retired Army General further urged Nigerians "to rise up defend your state against herdsmen attack".

Thus, the above statement by Danjuma has continued to attract criticisms from certain segments of the Nigerian State, particularly the military. This is because; the retired Army accused the Nigerian Armed Forces of colluding with bandits (Killer Herdsmen) to kill people (PM News, 2018). However, General Danjuma analytical disposition captured pathetic feelings of some security experts who bluntly argue that 'any insurgency that lasts more than four days implies that the military/or Armed Forces has a hand in it" (Oyedele, et al, 2018; Adeyemi, et al, 2018).

Generally, all these claims and counter claims point to the fact that the killings of innocent Nigerians by either Fulani Herdsmen or killer (hired) Herdsmen in the Northern part of Nigeria have continued to be on increase despite purport efforts of the Nigerian Military, particularly in the North. The analysts' positions are further justified by the recent killing of two Reverend Fathers and several parishioners by killer/herdsmen on their return from burial of their members. Thus, these religious leaders and their members were murdered by the armed bandits despite the existence of troops deployed to Benue State by the Buhari-led Federal Government.

The killing of the two Reverend Fathers and their members attracted protests by Catholic faithfuls across the 36 states of Nigeria and Federal Capital Territory (FCT) Abuja (Adeyemi, et al, 2018). These internal security challenges are still taking place despite claims by the Federal Government that Boko Haram has been defeated. The pathetic internal security challenges in Nigeria, particularly in the northern part of the country has not only militarized the Nigerian political space, but has also resulted to the recent abduction of Dapchi school children, suffering of large number of families in IDP camps, destruction of numerous lives and property of Nigerians, deterioration of the image of the country at global arena, and suffocation of economic development of Nigeria, particularly since 2015 . Consequently, the Nigeria's internal security architecture has been bastardized and the capacity of the state to justify her fundamental responsibility of protecting lives and property of the citizens are currently questionable.

The internal security situation in Nigeria iscurrently more worrisome as some public functionaries serving under President Muhammadu Buhari-led administration are calling on states in Nigeria such as Benue and Taraba to suspend Open Grazing Law which their StateHouse of Assemblies have already passed into law. It is evident that Benue and Taraba States are mostly affected by nefarious activities of Fulani Herdsmen. Similarly, both Christian and Moslem faithfuls cohibit in these two states. However, observers have asserted that in view of killing of Christians and bombing of churches in these two states (Benue and Taraba) by Fulani Herdsmen, depict deliberate attempt to stamp out christianity in both state. For some security experts, suspension or withdrawal of Anti-Grazing Bill implies the killing of more Christian population in the two states.

\section{Conclusion}

This paper has attempted with fair degree of objectivity, to expose the Nigeria's internal security challenges in the 21st Century. The study exposed the inadequacies of the internal security policies of Nigeria and the Nigerian Police Force (NPF) to tackle internal security challenges in Nigeria. However, the high level of unproductive disposition of the Nigerian Police and gross inadequacy of institutional manpower resulted to the involvement of the military in internal security architecture of the Nigerian State, which is mostly conceived as aberration. Thus, its aberration is rooted in theorization that continuous deployment of the military in internal security governance is capable of encouraging military intervention in any social formation.

Thus, this pathetic situation has resulted to multiferation of several criminal groups agitating one thing or the other against the local, state and federal governments in Nigeria. These criminal elements/groups include the Niger Delta militants, the Islamic extremists in Jos, the kidnappers in the South-East, the Boko Haram, Fulani Herdsmen, terrorist groups, among others.

Consequently, the activities of these unregistered group, and unlawful armed men and non-state actors which could not be effectively controlled/handled by both the internal security policies and security agencies have continued to impact negatively on the economy of the Nigerian State, particularly since 2011-2018. 
This ugly scenario partly explains why Nigeria witnessed serious economic recession, unable to pay public workers' salaries, exodus of foreign/multi-national companies, closures of indigenous manufacturing companies, low investment outlook in Nigeria, hunger/malnutrition among Nigerians, poor health status, low expectancy rate, tension, civil uprising, violent agitations, religious differences, hate speeches among others.

This, however, calls for stringent approach by policy makers, not only to effectively implement Nigeria's internal security policies to redress the identified challenges, but also to salvage the country from imminent disintegration as a federation.

\section{Recommendations}

To address the challenges posed by internal security in Nigeria, especially in this 21st Century, the following evidencebased policy recommendations are proffered:

The federal government of Nigeria should review the national security policy and include more robust ingredients capable of addressing the generational causes of internal security in the country such as poverty, unemployment, inequality, corruption, among others.

The Federal Government of Nigeria should adopt more stringent penalties for violent crimes such as those committed by Niger Delta militant group's avengers, kidnappers, Islamic extremists. Boko Haram groups, among others. This will serve as deterrent to youths that may form such criminal groups to intimidate government and her corporate existence in Nigeria.

Government at all levels in Nigeria should partner with corporate bodies to create employment for the Nigerian youths. This will discourage large number of idle youths from forming criminal groups against the citizens and thegovernment in the Nigerian State.

Since agriculture can accommodate large number of unemployed citizens in Nigeria, government should stop playing politics with it and give Zero Interest Loans (ZIL) to youths to embark on poultry farming, fish farming, cattle farming, snail farming, piggery, cassava farming, vegetable farming, among others. This will boost food production and further reduce hunger, unemployment, poverty and insecurity in Nigeria.

Federal, State and Local Governments should establish a more robust relationship with international institutions such as World Bank, Agricultural Development Bank, African Development banks, World Health Organization, UNDP, USAID, among others. This will enable these agencies empower large number of Nigerians in various fields of human endeavours. This will further reduce the spate of insecurity in the contemporary Nigerian State.

The National Assembly in Nigeria (Senate and House of Representatives), should enact a Law to address the citizenship debates in Nigeria. The new law should ensure that 'residency' rather than 'origin' of where one comes from, must be the basis of citizenship in Nigeria. This will address the internal security problems in Jos, and many parts of Nigeria.

The Nigerian Government should assist cattle farmers (both from Northern and Southern) Nigeria, with zero-interest loan facilities to establish ranches across the country. This will reduce the fiasco between farmers, Fulani Herdsmen and cattle rearers from the Southern part of Nigeria.

The appointment of Service Chiefs (Police, Army, Navy, Airforce, DSS and other Para-military services) in Nigeria should not reflect sectionalism or being perceived by Nigerian as ethnic-based, as evidenced from the actions of Mohammadu Buhari-led administration in his first tenure of office as the Nigerian President. This will ensure that Service Chiefs will see their positions as crucial, to protect lives and property of all Nigerians, irrespective of their origin, rather than a particular segment of the Nigeria State.

\section{References}

[1] Aderoju, O. (2008). Oil and the Profitability of Rebel Participation among Youths in Niger Delta. Journal of Peace Research, 45(4): 539-555.

[2] Adeyemi, M. \& Omofoye, T.; Umeh, K.; Akubo, J., Alabi, A.; Wantu, J., Akingboye, O., Akpeyi, C.; Afolabi, A.; Adewale, M. S., \& Abogonye, A. (2018). Christians protest, urge sack of service chiefs. The Guardian Newspaper, p. 1.

[3] Ajani, C. (2010). Abia Places 5 Million Ransom on Suspected Kidnappers. This Day Newspaper, October 4, 
p.3.

[4] Ajayi, D. (2011). Terrorism could not be fought by One Agency Alone. Tell Magazine, May 21, p48.

[5] Akinrinade, K. (2011). How an Alert Co-Passenger saved school boy from Kidnappers. The Nation Newspaper, May 28, P. 17.

[6] Akinterinwa, B. A. (2001). US National Security Strategy and Nigeria. The Nigeria Voice Newspaper, February 24, p.2.

[7] Akor, C. \& Twok, I. (2018). As Benue burns, Buhari focus on re-election, Ortom vacations in China.... Lawmakers condemn, summon President. Business Day Newspaper, P. I.

[8] Akpan, F. (2011). Turbulent System, Media and Conflict Reportage in Nigeria: Comparative Analysis of Niger Delta, Boko Haram and Jos crises. Available online at: http://www.unijospeace .worldpress.com/conference. Retrieved on January 4, 2017.

[9] Alaneme, E. (2011). We Created Boko Haram-Governor Shettima: Apologize for Killing. Sunday Champion Newspaper. June 12, p.3.

[10] Aliyu, M. B. (2011). The Search for National Security in Nigeria. A Public Lecture Delivered at Institute of Government and Public Policy. Obafemi Awolowo University, lle-lfe, September 27, 2011. Available Online at: http:www.obafemiawolowoigpp.com/home. Retrieved on December 29, 2017.

[11] Amaizu, J. (2011). Reps Propose Life Jail for Kidnappers, Hostage-takers. The Nation Newspaper, October 20, p. 14.

[12] Aminu, M.; Okoh, G. \& Ayodele, W. (2018). 53 killed by Suspected Herdsmen, bandits in Taraba, Zamfara, Benue: Death toll in Ukum Logo LGA attacks rises to 66. This Day Newspaper: p.1.

[13] Andrew, W. (2009). Africa: Will Nigeria Oil Offensive Backfire? Available Online at: http:www.news.bbc.co.Uk/2/hi/Africa/8068174.stm. Retrieved on October 7, 2011.

[14] Anofi, D. (2010).Bombs: I'm Empty, Say Dad who Lost Two Kids. The Nation Newspaper, October 8, p.I.

[15] Arizona-Ogwu, L. C. (2010). Kidnapping in South East Nigeria: Tracking Collaborators and Tracking Hidouts.Available online at: http://www.nigerianinamerica.com/arcticle/4333/1/kidnapping. Retrieved on December 10, 2016.

[16] Audu, OI. (2011). Jos Crisis: JTF Reassures Victims. Daily Independent Newspaper, August 10, p. 10.

[17] Awowole, B. (2010). Bombs Blast Victim to Lose one Eye. Daily Sun Newpaper, October 6, p.6.

[18] Bassey, C. O. (2007). Epidemiology of Conflict and Violence in Nigeria. In Bassey) C. O. and Oshita, O. O. (eds). Conflict Resolution, Identity Crisis and Development in Africa. Lagos: Malthouse Press.

[19] Bassey, C. O. (2011). The challenges of military state craft in Nigeria. In Bassey, C. O. \& Dokubo, C. Q. (eds). Defence policy of Nigeria: Capability and context-A reader. Bloomington: Author House.

[20] Chukwurah, H. (2011). How Kidnapped Corps Members were freed. Daily Sun Newspaper, p.9.

[21] Crises Group Report (2011). Curbing violence in Nigeria: The Jos Crisis. African Report, 196:17. Available online at: http://www.crisisgroup.org/en/regions/africa/west-africa/nigeria/190. Retrieved on January 15, 2017.

[22] Dafinone, D. (2008). How to End Niger Delta Crises. The Nation Newspaper, p.30.

[23] Danjuma, T. Y. (2018). Press Release: Re: Armed Forces collude with bandits to kill people. P. M. News; available online at: www.pmnewsnigeria.com. Retrieved on May 26, 2018.

[24] Dunia, N. (2010). Abuja Bomb Blast: Senate takes Decision Today, Daily Sun Newspaper, October 6, p.6.

[25] Dye, T. R. (1972). Understanding Public Policy. Englewood Cliffs: N. J. Prentice Hall. 
[26] Ekanem, S. A., Dada, J. A., and Ejue, B. J. (2011). Boko Haram and Amnesty: A Philosophical Appraisal. International Journal of Humanities and Social Science, 2(4): 231 -242

[27] Fayemi, K. J. (2003). Governing the Security Sector in a Democratizing Polity. In: Cawthra, G. and Luckham, R. (eds). Governing Insecurity: Democratic Control of Military and Security Establishment in Translational Democracies. New York: Zed Books.

[28] Federal Republic of Nigeria (2010). The Niger Delta. A Brief History. Port Harcourt: Niger Delta development Commission. Available Online at: http:www.nddconline.org/the-Niger-delta. Retrieved on May 18, 2018.

[29] Federal Republic of Nigeria (2011). Niger Delta Archive of News, Interview and Articles: Analysis from 1999 to present. Port Harcourt: Niger Delta Development Commission. Available Online at: http://vww.nigerdeltavine.com. Retrieved on May 10, 2018.

[30] Human Right Watch (2002). The Niger Delta Democratic Dividend.Available Online at: http://www.hrw.org/reports/2002/nigeria3/nigerdelta.pdf. Retrieved on May 7. 2018.

[31] Human Right watch Report (2010). Nigeria should Protect Survivors and fully investigates the Massacre in Jos. Available Online at: http:www.org/en/news/2010/01/Nigeria-protect-survivors-fully-investigate-massacrereports. Retrieved on:May 29, 2018.

[32] Idoko, N. (2008). Niger Delta: Challenge of Violence Control. The Nation Newspaper, July 8, p.20.

[33] Igbokwu, C. (2009). Kidnap Birth of Terror Merchandise. Daily Sun Newspapers. December 12, p. 4.

[34] Ikuomola, V. (2011). Boko Haram: Senator to stay in SSS Custody says Court. The Nigerian Newspaper, December 13, p.2.

[35] Mathiason. N. (2009). Shell in Court over Alleged Role in Nigeria Executions. The Guardian, April 5, p.30. Available online at: http://www.guradian.co.uk/business/2009 /apr/05/shell-saro-Execution-charges. Retrieve on May 7, 2018.

[36] Mitee, L. (2009). The Niger Delta: A Vision of Nigeria's Development. A Paper presented at $5^{\text {th All Nigeria }}$ Editors Conference Held in Kaduna on April 3, 2009. The Nigerian Chronicle Newspaper, April 4, p.8.

[37] Nakande, B.(2011). Jos Crisis: Hausa/Fulani Leaders meet Jonathan Available Online at: http://www.nm.onlinenigeria.com/tcmplates/16096. Retrieved on May 17, 2018.

[38] Nigerian Watch Organization (2018). 10 myths about violence in Nigeria. Available online at; www.nigerian watch.org. Retrieved on May 26, 2018.

[39] Nnoli, O. (2006). National Security in Africa: A Radical New Perspective, Enugu: Pacrep.

[40] Nwogu, M. (2008). How Abia State Governor Missed Gunmen's Bullets. Daily Sun Newspaper, p.4.

[41] Nwosu, I. (2011). Reps Urge IGP to end Kidnapping in South-East. Available online at: http://www.odili.net/./516.html. Retrieved onJune 7, 2018.

[42] Obateru, T. and Omonobi, K. (2010). Jos Crisis: Varsity Student Killed. Worker Missing: US Offers to Train Police in Handling Disturbances. Vanguard Newspaper, p. 10.

[43] Obi, N. B. (2011). The Boko Haram Nightmare.TheNews Magazines, March 26. P. 16.

[44] Obi, P.; Sani, D. \& Aminu, M. (2018). 28 killed in Herdsmen, cattle rustlers attacks in Adamawa, Zamfara: Army arrests armedherders in Benue. This Day Newspaper, p.12.

[45] Ogbodo, S. M. (2010). Environmental Issues and Nigeria's Niger Delta Crisis: Implication for Sustainable Development and Global Peace. OIDA International Journal of Sustainable Development, 12(2): 125-173.

[46] Ojiabor, O. (2011). Boko Haram, Abuja and the Rest of Us. The Nation Newspaper, December 26, p.3. 
[47] Ojiabor, O. (2011). Those who died in Boko Haram Attacks. The Nation Newspaper, November 10, p. 10.

[48] Okoli, A. (2009). Help us Flush Kidnappers, Abia Governor Begs Army: Situation Beyond Police Capacity. Vanguard Newspaper, June 10, p. 1.

[49] Oladesu, E. (2008). Only Niger Deltans can solve their problems. The Nation Newspaper, August 29, p.30.

[50] Oladoyinbo, Y. (2010). Jos Crisis is over Culture and Dispute. Sunday Tribune Newspaper, January 23, p.6.

[51] Olaniyi, S. \& Nzeagwu, U. (2018). ArmyProbes allegation of collusion in Benue, Taraba killings. The Guardian Newspaper,P.3.

[52] Olugbode, M. (2010). F. G. DeploysTroops as Boko Haram Bombs PoliceStation. This Day Newspaper, October 13, p.1

[53] Onoyume, J. (2008). Navy kills Militant, Arrest Three. Vanguard Newspaper, January 22, p.9.

[54] Oyedele, D.; Ogunmade, O. \& Okoh, G. (2018). Senate joins house, summons Buhari over killings. This Day Newspaper, p.1.

[55] Rotimi, F. (2009). Amnesty and the Niger Delta Crisis. Vanguard Newspaper, June 30, p.15.

[56] Sampson, O. (2010). Soldiers Storm Kidnappers' Hideout in Ukwe West. Daily Sun Newspaper, October 7 , p.6.

[57] Soriwei, F. (2011). Kidnappers Reduce Ransom on Transport Magnate's Wife to $110 \mathrm{~m}$. The Punch Newspaper, April, 29, p. 12.

[58] Terminski, B. (2003). Oil-Induced Displacement and Resettlement: Social Problem and Human Right Issue. Available Online at?: http://www.confilicfrecovery. org.bin.bongumil-terminski. Retrieved on June 7, 2018.

[59] Wale, F. (2009). Niger Delta Offensive Intensifies. Available Online at: http://www.23next.com/csp/cms/sites/next/news/national/5418588-146. Retrieved on June 9, 2018. 